\title{
Different digestion of caprine whey proteins by human and porcine gastrointestinal enzymes
}

\author{
Ellen K. Eriksen ${ }^{1}$, Halvor Holm ${ }^{2}$, Einar Jensen ${ }^{3}$, Ragnhild Aaboe ${ }^{1}$, Tove G. Devold ${ }^{1}$, Morten Jacobsen ${ }^{1,4}$ \\ and Gerd E. Vegarud ${ }^{1}$ \\ ${ }^{1}$ Department of Chemistry, Biotechnology and Food Science, Norwegian University of Life Sciences, N-1432 As, Norway \\ ${ }^{2}$ Institute of Nutrition, University of Oslo, Rikshospitalet and Radiumhospitalet University Hospital, 0027 Oslo, Norway \\ ${ }^{3}$ Department of Pharmacy, University of Troms $\phi, 9037$ Troms $\phi$, Norway \\ ${ }^{4}$ Oestfold Hospital Trust, Fredrikstad, Norway
}

(Received 29 June 2009 - Revised 2 February 2010 - Accepted 3 February 2010 - First published online 22 March 2010)

\begin{abstract}
The objective of the present study was twofold: first to compare the degradation patterns of caprine whey proteins digested with either human digestive juices (gastric or duodenal) or commercial porcine enzymes (pepsin or pancreatic enzymes) and second to observe the effect of gastric $\mathrm{pH}$ on digestion. An in vitro two-step assay was performed at $37^{\circ} \mathrm{C}$ to simulate digestion in the stomach (pH 2,4 or 6$)$ and the duodenum (pH 8 ). The whey proteins were degraded more efficiently by porcine pepsin than by human gastric juice at all $\mathrm{pH}$ values. Irrespective of the enzyme source, gastric digestion at $\mathrm{pH} 2$ followed by duodenal digestion resulted in the most efficient degradation. Lactoferrin, serum albumin and the Ig heavy chains were highly degraded with less than $6 \%$ remaining after digestion. About 15,56 and $50 \%$ Ig light chains, $\beta$-lactoglobulin ( $\beta$-LG) and $\alpha$-lactalbumin remained intact, respectively, when digested with porcine enzymes compared with 25,74 and $81 \%$ with human digestive juices. For comparison, purified bovine $\beta-L G$ was digested and the peptide profiles obtained were compared with those of the caprine $\beta$-LG in the digested whey. The bovine $\beta-\mathrm{LG}$ seemed to be more extensively cleaved than the caprine $\beta$-LG in the whey. Commercial enzymes appear to digest whey proteins more efficiently compared with human digestive juices when used at similar enzyme activities. This could lead to conflicting results when comparing human in vivo protein digestion with digestion using purified enzymes of non-human species. Consequently the use of human digestive juices might be preferred.
\end{abstract}

Human gastric juice: Human duodenal juice: Commercial porcine enzymes: Whey proteins: $\beta$-Lactoglobulin

In vivo digestion of proteins is a complex process depending on several factors such as (a) the amount and composition of the digestive enzymes, (b) the $\mathrm{pH}$, (c) the transit time in the various parts of the gastrointestinal tract and (d) the overall composition of the food ingested ${ }^{(1-3)}$.

Human digestion of milk and milk-derived products may release peptides of different sizes available for paracellular or transcellular uptake and thus enter the systemic circulation and exert biological effects ${ }^{(4,5)}$. Several bioactive peptides have in the recent years been identified after in vitro enzymic digestion of milk proteins. Most of these studies have applied commercial digestive enzymes often of porcine origin ${ }^{(6-10)}$. Although commercial porcine enzymes provide an easyto-use option to study in vitro digestion, their validity in mimicking physiological digestion might be questioned. Human digestive juices consist of a variety of enzymes, inhibitors and bile salts that collectively contribute to the digestion of macromolecules ${ }^{(11,12)}$

In vitro gastric digestion assays have frequently been performed at $\mathrm{pH} 1-2^{(3,8,10,13)}$. However, gastric $\mathrm{pH}$ varies from 1.0 to 3.5 in the fasting state of healthy adult individuals $^{(14)}$ and increases to a median of 6.7 during a meal ${ }^{(15)}$. The type of food ingested ${ }^{(2)}$ will also influence the gastric $\mathrm{pH}$. In cases with short transit times (liquid food) or with high buffering capacity of the food, the $\mathrm{pH}$ may never decrease to the levels used in most assays. Furthermore, patients suffering from gastro-oesophageal reflux disease are frequently treated with proton pump inhibitors (PPI) leading to steady-state gastric $\mathrm{pH}$ values of $>4$ for $24 \mathrm{~h}$ to diminish oesophageal injury ${ }^{(16)}$. The activity of the gastric proteases (pepsins) is highly influenced by $\mathrm{pH}$, with decreased activity above $\mathrm{pH} 4 \cdot 5^{(12)}$. Low activity of the pepsins delays gastric protein digestion, resulting in an increased amount of intact protein reaching the intestine. During duodenal digestion, the $\mathrm{pH}$ is normally about $6 \cdot 2-6 \cdot 7^{(3,17)}$; however, $\mathrm{pH}$ values up to $7-8$ are recorded both in in vivo and in vitro studies $^{(18,19)}$.

We investigated whether digestion of caprine whey proteins would produce bioactive peptides. To do this, an in vitro method that would mimic the events taking place during

Abbreviations: IgHC, Ig heavy chains; IgLC, Ig light chains; $\alpha$-LA, $\alpha$-lactalbumin; LF, lactoferrin; $\beta$-LG, $\beta$-lactoglobulin; SA, serum albumin; WPCG, caprine whey protein concentrate.

* Corresponding author: Ellen K. Eriksen, fax +47 649659 01, email ellen.eriksen@umb.no 
human gastrointestinal digestion was needed. Consequently, the aim of the present study was to compare the degradation of caprine whey proteins digested with either human digestive juices or with commercial porcine digestive enzymes. In addition, the effect of different gastric $\mathrm{pH}$ values, 2, 4 or 6, on the gastroduodenal degradation of the proteins was studied.

Whey proteins consist primarily of $\beta$-lactoglobulin ( $\beta$-LG), $\alpha$-lactalbumin ( $\alpha$-LA), lactoferrin (LF), serum albumin (SA) and immunoglobulins. The main protein is $\beta-\mathrm{LG}$, making up about $50-60 \%$ of the protein fraction of both caprine and bovine whey ${ }^{(20,21)}$. Whey proteins are considered high-quality proteins due to their elevated content of essential amino acids and are used to increase muscle gain in athletes ${ }^{(22)}$ as well as for the elderly ${ }^{(23)}$. Moreover, whey proteins are rich sources of bioactive peptides ${ }^{(24-27)}$. The $\beta-L G$ peptide produced during the in vitro digestion of caprine whey proteins was compared with bovine $\beta$-LG peptides obtained with the same enzymes at gastric $\mathrm{pH} 2$.

\section{Materials and methods}

\section{Materials}

Whey protein concentrate from goats' milk (caprine whey protein concentrate; WPCG) was produced from sweet, cheese whey with a protein content of $81 \%{ }^{(28)}$. Bovine $\beta-\mathrm{LG}$ was purchased from Arla Foods $(95 \%$, variant A + B; Arla Foods, Videbæk, Denmark; PSDI-2400). Pepsin A (77 163, $655 \mathrm{U} / \mathrm{mg}$ ) was isolated from porcine stomach mucosa (Fluka BioChemika, Buchs, Switzerland) and Corolase PP (Ch 6946; 350 proteolyticU/mg) derived from pig pancreas glands, a mixture of trypsin, chymotrypsin amylase, lipase and several amino- and carboxypeptidases (Röhm $\mathrm{GmbH}$, Darmstadt, Germany), was used. Hb from bovine blood was provided by Sigma (St Louis, MO, USA) and Hammarstein casein was purchased from Merck Co. (Darmstadt, Germany). All reagents used for HPLC and MS were of HPLC grade.

\section{Aspiration of human gastric and duodenal juices}

To follow up and extend previous work on in vitro digestion of caprine whey ${ }^{(28-30)}$ the gastric and duodenal juices employed were obtained from the same individual (healthy male, no medication). The pepsin and total proteolytic activities of these juices were within the normal range observed in twelve individuals (men and women, preliminary results). The proteolytic enzymes were obtained in the activated state by collecting human gastric and duodenal juices according to Holm et al. ${ }^{(31)}$. In brief, a three-lumen tube (Maxter Catheters, Marseille, France) enabled both simultaneous instillation of stimulation solution in the duodenum, and aspiration of gastric and duodenal juices. The stimulation solution $(70 \mathrm{~g} / \mathrm{l}$ sucrose, $1.8 \mathrm{~g} / \mathrm{l} \mathrm{NaCl}, 3.2 \mathrm{~g} / \mathrm{l} \mathrm{L}$-phenylalanine and $2.3 \mathrm{~g} / \mathrm{l} \mathrm{L}$-valine in water) was instilled close to the papilla of Vater $(100 \mathrm{ml} / \mathrm{h})$ to stimulate the production of pancreatic enzymes and the human duodenal juices was aspirated some $18 \mathrm{~cm}$ distally. Aspirates were collected on ice, centrifuged $(4500 \mathrm{~g}$ for $10 \mathrm{~min})$ to remove mucous and cell debris before being frozen in samples and stored at $-20^{\circ} \mathrm{C}$ before use.

\section{Enzymic activities of gastric and duodenal enzymes}

Porcine pepsin A and human gastric juices were analysed for pepsin activity at $\mathrm{pH} 3.0$ with $\mathrm{Hb}$ as substrate as described by Sánchez-Chiang et al. $^{(32)}$. Corolase PP and human duodenal juices were analysed for total proteolytic activity at $\mathrm{pH} 8.0$ with casein as substrate, as described by Krogdahl \& $\mathrm{Holm}^{(33)}$. In brief, the enzymes were incubated with substrate for $10 \mathrm{~min}$ at $37^{\circ} \mathrm{C}$ and the reactions were stopped by the addition of TCA. After an overnight sedimentation at $4^{\circ} \mathrm{C}$ the samples were centrifuged for $10 \mathrm{~min}$ at $3000 \mathrm{~g}$ and $4^{\circ} \mathrm{C}$. The enzymic activities were measured as the difference in absorbance at $280 \mathrm{~nm}$ of the TCA soluble fractions. One unit of enzyme activity (U) was defined as the amount ( $\mathrm{ml}$ or $\mathrm{mg}$ ) of enzyme giving a difference in absorbance of 1.0 at $280 \mathrm{~nm}$ in $10 \mathrm{~min}$ at $37^{\circ} \mathrm{C}$. The enzyme assays were run in triplicate and performed three or more times.

In vitro digestion of caprine whey proteins and bovine $\beta$-lactoglobulin

A two-step in vitro protein digestion assay (Fig. 1) was performed in duplicate at $37^{\circ} \mathrm{C}$ to simulate digestion in the stomach and duodenum as described by Almaas et al. ${ }^{(28)}$. Either human digestive juices or porcine enzymes were used at similar enzymic activities. In the first step, simulating gastric digestion, the $\mathrm{pH}$ was adjusted to 2,4 or 6 with $2 \mathrm{M}-\mathrm{HCl}$ and $5 \mathrm{U}$ of porcine pepsin $\mathrm{A}$ or human gastric juices was added per $g$ protein in the solution. The second step simulating duodenal digestion was performed by adjustment to $\mathrm{pH} 8$ with $2 \mathrm{M}-\mathrm{NaOH}$ adding $16 \mathrm{U}$ of either Corolase PP or human duodenal juices per $g$ protein in the solution. Both steps lasted $30 \mathrm{~min}$ and samples were extracted at the start, during step 1 (at 10, 20 and $30 \mathrm{~min}$ ) and during step 2 (at 15 and $30 \mathrm{~min}$ ). Samples were transferred directly on ice and frozen within 5 min to stop the enzymic reactions. For comparison, bovine $\beta-\mathrm{LG}$ was digested in duplicate only at gastric $\mathrm{pH} 2$ at the same conditions as described above.

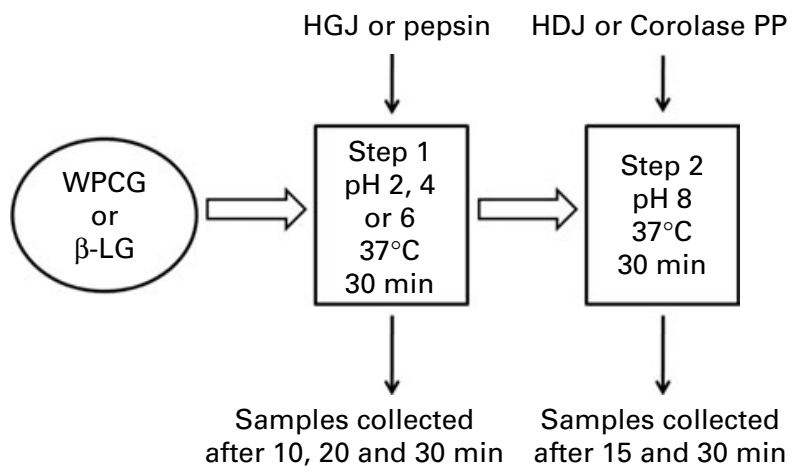

Fig. 1. Illustration of the in vitro digestion assay performed in two steps using either human or porcine gastrointestinal enzymes ${ }^{(28)}$. Whey protein concentrate from caprine milk (WPCG) or bovine $\beta$-lactoglobulin ( $\beta-L G)$ were digested at $37^{\circ} \mathrm{C}$ in two $30 \mathrm{~min}$ steps to simulate the digestion in the stomach and the duodenum. Samples were extracted 10,20 and $30 \mathrm{~min}$ after the addition of human gastric juice (HGJ) or porcine pepsin, and after 15 and $30 \mathrm{~min}$ following the addition of human duodenal juice (HDJ) or Corolase PP. Step 1 was perfomed at $\mathrm{pH} 2,4$ or 6 for WPCG, and at $\mathrm{pH} 2$ for $\beta$-LG. 
Visualisation of protein degradation by SDS-PAGE and ImageQuantTL analysis

The degradation profiles of the whey proteins were assayed by SDS-PAGE using the Bio-Rad Mini-PROTEAN ${ }^{\circledR} 3$ Cell system (Bio-Rad Laboratories Ltd, Hemel Hempstead, Herts, UK). Each sample was run at least four times. Standard Laemmli reagents ${ }^{(34)}$ and protocols were used to visualise protein degradation on $15 \%$ polyacrylamide separating gels. Hydrolysates were mixed with $2 \times$ SDS sample buffer (0.125 M-2-amino-2-hydroxymethyl-propane-1,3-diol-HCl, $\mathrm{pH}$ $6.8,4 \%$ SDS, $20 \%$ glycerol, $2 \%$ 2-mercaptoethanol, $0.03 \mathrm{~mm}$-bromphenol blue) and boiled for $5 \mathrm{~min}$ before application to the gel. A low-molecular-weight marker (LMW-SDS Marker Kit; GE Healthcare, Little Chalfont, Bucks, UK) was used. Electrophoresis was performed at constant $200 \mathrm{~V}$ for $50 \mathrm{~min}$ and Coomassie Brilliant Blue R-250 was used to visualise the separated proteins. To evaluate the degree of protein degradation, the ImageQuantTL 7.0 software (GE Healthcare Bio-Sciences, Uppsala, Sweden) was used. The individual protein bands in the undigested WPCG were set to $100 \%$ and the percentage remaining was calculated based on the average of at least four gels.

\section{In-gel digestion of caprine whey protein concentrate proteins}

Whey proteins were separated on a $15 \%$ SDS-PAGE gel. Each band (1-6; Fig. 2(a)) was excised out of the gel, and subjected to in-gel reduction, alkylation, and tryptic digestion $^{(35)}$. In brief, $10 \mathrm{~mm}$-dithiothreitol in $100 \mathrm{~mm}$ ammonium bicarbonate (Ambic) was added to reduce the cystines $\left(56^{\circ} \mathrm{C} ; 45 \mathrm{~min}\right)$. Cysteine alkylation was carried out in the dark in a solution of $55 \mathrm{~mm}$-iodoacetamide in $100 \mathrm{~mm}$-Ambic (room temperature; $30 \mathrm{~min}$ ). In-gel digestion was performed using $6 \mathrm{ng} / \mu \mathrm{l}$ trypsin (V511A; Promega Corp., Madison, WI, USA) in $50 \mathrm{~mm}$-Ambic containing $5 \mathrm{mM}-\mathrm{CaCl}_{2}\left(37^{\circ} \mathrm{C}\right.$, overnight $)$. Before the mass spectrometer analyses, the trypsinated proteins were desalted and concentrated using C18 ZipTips (OMIX; Varian, Inc., Palo Alto, CA, USA) according to the manufacturer's instructions.
Elution was performed with $2 \mu \mathrm{l} 0.1 \%$ formic acid in $60 \%$ acetonitrile and diluted in $8 \mu \mathrm{l} 0.1 \%$ formic acid.

\section{Prefractionation of digested proteins using size exclusion chromatography}

Size exclusion chromatography was used to improve the separation of peptides and remove undigested proteins in the hydrolysates before mass spectrometric analyses. Freezedried samples of digested caprine whey proteins and bovine $\beta$-LG were dissolved to a concentration of $4 \mathrm{mg} / \mathrm{ml}(\mathrm{w} / \mathrm{v})$ in a $100 \mathrm{~mm}$-sodium acetate buffer mixed containing $30 \%$ $(\mathrm{v} / \mathrm{v})$ acetonitrile and $0.1 \%(\mathrm{v} / \mathrm{v})$ trifluoroacetic acid at $\mathrm{pH}$ 5.5 (mobile phase). The samples were sterile filtered $\left(0.22 \mu \mathrm{m}\right.$ Millex ${ }^{\circledR}$ GP filter, Millipore Express ${ }^{\circledR}$ polyethersulfone (PES) membrane; Millipore Corp., Billerica, MA, USA) and samples of $50 \mu \mathrm{l}$ were added at a flow rate of $0.5 \mathrm{ml} / \mathrm{min}$. Fractionation was carried out on a Tricorn ${ }^{\mathrm{TM}}$ Superdex Peptide 10/300 GL gel filtration column (GE Healthcare) with a linear separation range from 100 to $7000 \mathrm{Da}$. Both duplicates from the in vitro digestion assays were run seven or more times and the resulting peaks were collected and freeze dried.

\section{Desalting and concentration of peptides}

Freeze-dried peptide fractions (peaks) prepared by size exclusion chromatography were dissolved in $0.1 \%(\mathrm{v} / \mathrm{v})$ formic acid. The samples were desalted and concentrated using self-made columns consisting of $\mathrm{C} 18$ column material (3M Empore C18 extraction disks; 3M Bioanalytical Technologies, St Paul, MN, USA) inserted into Eppendorf GELoader micropipette tips (Eppendorf, Hamburg, Germany). The peptides were eluted using $2 \mu \mathrm{l} 70 \%$ acetonitrile-0.1\% formic acid $(\mathrm{v} / \mathrm{v})$.

\section{Nano-LC MS of peptides}

Desalted and concentrated mixtures of peptides were diluted in $10 \mu \mathrm{l} 1 \%(\mathrm{v} / \mathrm{v})$ formic acid before they were loaded onto a nanoACQUITY ${ }^{\mathrm{TM}}$ Ultra Performance LC $^{\circledR}$ (Waters Corp.,

\begin{tabular}{|c|c|c|c|c|c|c|}
\hline 5 & $\begin{array}{l}1 \\
2 \\
3\end{array}$ & Band protein & Species & Accession no. & $\begin{array}{l}\text { Sequence } \\
\text { coverage }\end{array}$ & Score \\
\hline & & 1 Lactoferrin & Capra hircus & gi88702503 & $21 \%$ & 721 \\
\hline & & 2 Serum albumin & Ovis aries* & gi57164373 & $34 \%$ & 895 \\
\hline & & 3 Immunoglobulin heavy chains & Capra hircus & gi147744654 & $34 \%$ & 137 \\
\hline & & 4 Immunoglobulin light chains & Capra hircus & gi61378762 & $19 \%$ & 204 \\
\hline & 5 & $5 \beta$-Lactoglobulin & Capra hircus & gi125912 & $48 \%$ & 574 \\
\hline & 6 & $6 \alpha$-Lactalbumin & Capra hircus & gi125998 & $19 \%$ & 141 \\
\hline
\end{tabular}

Fig. 2. Proteins identified in the caprine whey protein concentrate. (a) Proteins separated as individual bands by SDS-PAGE. (b) Identification of the protein band by nano-LC MS/MS. * All identified peptides were also present in serum albumin from Capra hircus; the mascot software did, however, not list this species. † Percentage of protein sequence covered by the identified peptides. 
Milford, MA, USA), containing a $3 \mu \mathrm{m}$ Symmetry ${ }^{\circledR}$ C18 Trap column $(180 \mu \mathrm{m} \times 22 \mathrm{~mm}$; Waters $)$ in front of a $3 \mu \mathrm{m}$ Atlantis $^{\mathrm{TM}}$ C18 analytical column $(100 \mu \mathrm{m} \times 100 \mathrm{~mm}$; Waters). Peptides were separated with a gradient of 5-90\% (v/v) acetonitrile, $0.1 \%(\mathrm{v} / \mathrm{v})$ formic acid, with a flow of $0.4 \mu \mathrm{l} / \mathrm{min}$ eluted to a Q-TOF Ultima Global mass spectrometer (Micromass/Waters) and subjected to data-dependent tandem MS analysis. Peak lists were generated by the ProteinLynx Global server software (version 2.1), and the resulting pkl files were searched against the National Center for Biotechnology Information (NCBI) non-redundant protein sequence databases using the MASCOT search engine (http://www.matrixscience.com). Peptide mass tolerances used in the search were 100 parts per million (ppm), and fragment mass tolerance was $0 \cdot 1 \mathrm{Da}$. The taxonomy used in the search was mammalia. Data were acquired over a mass:charge ratio of 400-1500 Da, detecting peptides with two or three charges. Thus, only peptides with mass above 800 and below $4500 \mathrm{Da}$ were subjected to collision-induced fragmentation and further processing.

\section{Statistical analysis}

Statistical evaluation of the effect of enzyme source (porcine or human) and $\mathrm{pH}(2,4$ and 6$)$ on protein degradation was performed on four or more SDS-PAGE gel runs per sample using Minitab 15 (Minitab Inc., State College, PA, USA). The experiment was designed as a $2 \times 3$ unbalanced factorial design, and a two-way ANOVA (general linear model) was used to analyse the results with Tukey's test for pairwise comparisons. The percentage remaining of each intact protein band after 10, 20 and $30 \mathrm{~min}$ gastric digestion or after 45 or $60 \mathrm{~min}$ gastric and duodenal digestion was compared at the $P<0.05$ level. Bartlett's and Levene's tests were used to test for equal variances after transforming the data by the square root. The tests found unequal variances only for the means of the Ig heavy chains (IgHC). Nevertheless, these results were included in the further analysis.

\section{Results}

\section{Identification of proteins in the caprine whey protein} concentrate

The major proteins in the caprine whey as visualised by SDSPAGE were identified by in-gel trypsination followed by nano-LC MS/MS analysis (Fig. 2). Bands 1-6 were identified as the following proteins (molecular weight in decreasing order): LF, SA, IgHC, Ig light chains (IgLC), $\beta-\mathrm{LG}$ and $\alpha-\mathrm{LA}$.

\section{Effect of $p H$ and enzyme source on the digestion of whey proteins}

The amounts (\%) of intact whey proteins remaining after gastric and duodenal digestion are shown in Table 1. Gastric $\mathrm{pH}$ had a significant effect on the proteolysis of all the proteins $(P<0.001)$ except for $\beta$-LG $(P=0.385)$, with $\mathrm{pH} 2$ resulting in the most extensive degradation. Furthermore, based on the amount of intact proteins, the porcine pepsin was overall more efficient than the human gastric juice at degrading the whey proteins. Digestion at gastric $\mathrm{pH} 4$ followed by duodenal
Table 1. Amount of intact protein remaining (\%) after digestion of caprine whey proteins with either human digestive juices or porcine enzymes

(Mean values and standard deviations)

\begin{tabular}{|c|c|c|c|c|c|c|c|c|}
\hline & \multicolumn{4}{|c|}{ Gastric digestion† } & \multicolumn{4}{|c|}{$\begin{array}{l}\text { Gastric and duodenal } \\
\text { digestion } \neq\end{array}$} \\
\hline & \multicolumn{2}{|c|}{ HGJ } & \multicolumn{2}{|c|}{ Pepsin A } & \multicolumn{2}{|c|}{$\begin{array}{l}\text { HGJ and } \\
\text { HDJ }\end{array}$} & \multicolumn{2}{|c|}{$\begin{array}{l}\text { Pepsin A } \\
\text { and CPP }\end{array}$} \\
\hline & Mean & SD & Mean & SD & Mean & SD & Mean & SD \\
\hline \multicolumn{9}{|l|}{ LF } \\
\hline $\mathrm{pH} 2$ & 19 & 7 & $2^{\star \star}$ & 1 & 1 & 2 & 2 & 1 \\
\hline $\mathrm{pH} 4$ & 61 & 9 & 50 & 5 & 21 & 6 & 31 & 5 \\
\hline $\mathrm{pH} 6$ & 96 & 13 & 81 & 13 & 64 & 16 & 60 & 12 \\
\hline \multicolumn{9}{|l|}{ SA } \\
\hline $\mathrm{pH} 2$ & 32 & 8 & $5^{\star \star}$ & 5 & 3 & 2 & 2 & 2 \\
\hline $\mathrm{pH} 4$ & 69 & 17 & $25^{\star *}$ & 7 & 29 & 9 & $16^{*}$ & 4 \\
\hline $\mathrm{pH} 6$ & 102 & 15 & 92 & 11 & 97 & 19 & 88 & 24 \\
\hline \multicolumn{9}{|l|}{$\lg \mathrm{HC}$} \\
\hline $\mathrm{pH} 2$ & 72 & 7 & $6^{* *}$ & 3 & 5 & 2 & 2 & 1 \\
\hline $\mathrm{pH} 4$ & 108 & 18 & $78^{\star *}$ & 14 & 79 & 22 & 62 & 10 \\
\hline $\mathrm{pH} 6$ & 114 & 20 & 99 & 18 & 94 & 23 & 90 & 25 \\
\hline \multicolumn{9}{|l|}{$\operatorname{IgLC}$} \\
\hline $\mathrm{pH} 2$ & 67 & 14 & $28^{\star *}$ & 10 & 25 & 6 & 15 & 7 \\
\hline $\mathrm{pH} 4$ & 111 & 21 & $74^{\star *}$ & 8 & 63 & 13 & 54 & 23 \\
\hline pH 6 & 110 & 9 & 104 & 11 & 53 & 13 & 44 & 9 \\
\hline \multicolumn{9}{|l|}{$\beta-L G$} \\
\hline $\mathrm{pH} 2$ & 112 & 20 & $90^{*}$ & 14 & 74 & 9 & $56^{\star}$ & 11 \\
\hline $\mathrm{pH} 4$ & 116 & 11 & $97^{*}$ & 11 & 89 & 12 & 89 & 12 \\
\hline pH 6 & 105 & 14 & 103 & 13 & 99 & 13 & 100 & 15 \\
\hline \multicolumn{9}{|l|}{$\alpha-\mathrm{LA}$} \\
\hline $\mathrm{pH} 2$ & 105 & 8 & $66^{\star \star}$ & 9 & 81 & 10 & $50^{\star \star}$ & 16 \\
\hline $\mathrm{pH} 4$ & 115 & 14 & $94^{*}$ & 9 & 120 & 15 & 96 & 8 \\
\hline $\mathrm{pH} 6$ & 108 & 15 & 99 & 8 & 111 & 16 & 104 & 20 \\
\hline
\end{tabular}

HGJ, human gastric juice; HDJ, human duodenal juice; CPP, Corolase PP; $\mathrm{LF}$, lactoferrin; SA, serum albumin; IgHC, Ig heavy chains; IgLC, Ig light chains; $\beta$-LG, $\beta$-lactoglobulin; $\alpha$-LA, $\alpha$-lactalbumin.

Mean value was significantly different from that when using human digestive juices at the same $\mathrm{pH}:{ }^{*} P<0.05,{ }^{\star \star} P<0.01$.

† Gastric digestion was with either HGJ or porcine pepsin A performed at $\mathrm{pH} 2,4$ or 6. Average numbers are based on four SDS-PAGE gels or more.

¥ Gastric digestion was followed by duodenal digestion at $\mathrm{pH} 8$ using either HDJ or porcine pancreatic enzymes (CPP). Average numbers are based on four SDS-PAGE gels or more.

digestion resulted in lower degradation of all the proteins with both porcine and human enzymes. However, the porcine pepsin and pancreatic enzymes seemed to be more efficient than the human digestive juices. At gastric $\mathrm{pH} 6$, very low degradation of all proteins was observed for both types of gastric enzymes (approximately 80-100\% intact protein), with the consequence of reduced duodenal digestion.

The degradation profiles of the digested whey proteins at gastric pH 2 are shown in Fig. 3. Fig. 3 illustrates differences in the degradation of the minor proteins LF, SA and $\mathrm{Ig}$, and the main proteins, $\beta-\mathrm{LG}$ and $\alpha$-LA, in whey by human and porcine enzymes. Porcine pepsin A digested the LF, SA and $\operatorname{IgHC}$ and IgLC efficiently, leaving only 2, 5, 6 and $28 \%$ intact proteins, respectively. In comparison, significantly more intact protein was detected $(P<0.0001)$ when human gastric juice was used, with 19, 32, 72 and $67 \%$ of the LF, $\mathrm{SA}$ and $\mathrm{IgHC}$ and IgLC remaining, respectively. However, digestion with human gastric and duodenal juices resulted in a rapid degradation of the $\mathrm{LF}, \mathrm{SA}, \operatorname{IgHC}$ and $\operatorname{IgLC}(1,3,5$ and $25 \%$ intact protein). 

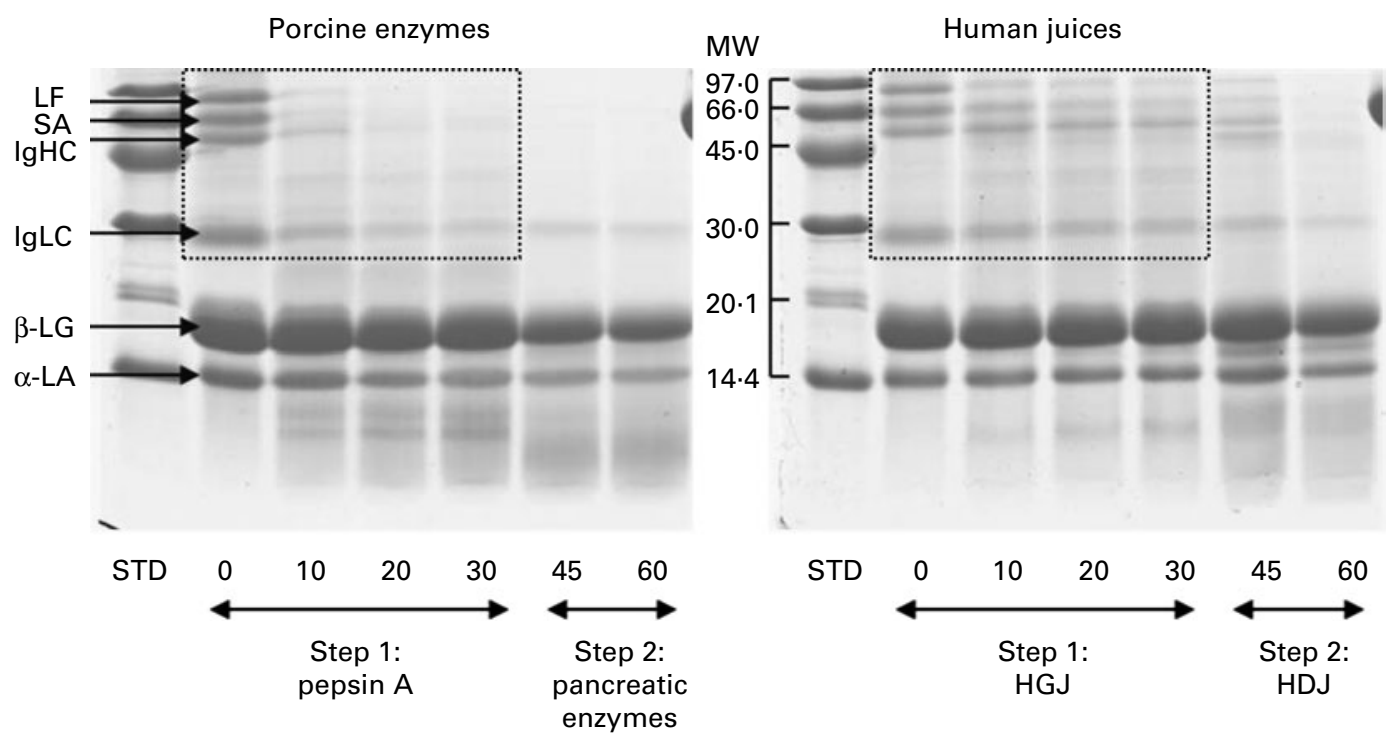

Fig. 3. SDS-PAGE (15\%) protein profiles of caprine whey protein concentrate (WPCG) digested with either human gastroduodenal juices or porcine digestive enzymes. Step 1: gastric digestion at pH 2. Step 2: duodenal digestion at pH 8. In both gels: lane 1, low-molecular-weight (LMW) marker; lane 2, undigested WPCG; lanes 3-5, WPCG digested with gastric enzymes (pepsin A or human gastric juice (HGJ)) for 10, 20 and 30 min; lanes 6 and 7, WPCG digested with gastric enzymes for $30 \mathrm{~min}$ followed by duodenal enzymes (porcine pancreatic enzymes or human duodenal juice (HDJ)) for 15 min (total time 45 min) and 30 min (total time $60 \mathrm{~min}$ ). The molecular weights (MW) of the standards (STD) (LMW, in kDa) are marked at the side of the gel showing the digestion of WPCG with human enzymes. The framed areas show the proteins in whey where the most pronounced difference in enzyme source was observed. Arrows indicate the main bands before digestion: lactoferrin (LF); serum albumin (SA); Ig heavy chains (IgHC); Ig light chains (IgLC); $\beta$-lactoglobulin ( $\beta$-LG); $\alpha$-lactalbumin ( $\alpha$-LA).

The main whey proteins, $\beta$-LG and $\alpha$-LA, seemed very resistant to gastric degradation with human gastric juices, whereas the porcine pepsin was significantly more efficient, leaving $90 \% \beta$-LG intact $(P=0.0253)$ and $66 \% \alpha$-LA intact $(P<0.0001)$. The following duodenal digestion with the porcine pancreatic enzymes resulted in 56 and $50 \%$ protein remaining, respectively, compared with a significantly higher amount observed with human gastroduodenal enzymes, $74 \%$ $\beta$-LG $(P=0.0285)$ and $81 \% \alpha$-LA $(P=0.0003)$.

Special attention was paid to the degradation of LF, an antibacterial protein in whey, with time (Fig. 4). Within the 30 min gastric digestion at $\mathrm{pH} 2$, the porcine pepsin A was significantly more efficient $(P<0.0001)$ compared with human gastric juice and only $6 \%$ intact LF remained after $10 \mathrm{~min}$. Human gastric juices resulted in a more gradual degradation, with approximately $36 \% \mathrm{LF}$ remaining after $10 \mathrm{~min}$ and $19 \%$ remaining after $30 \mathrm{~min}$. Gastric $\mathrm{pH} 4$ resulted in a

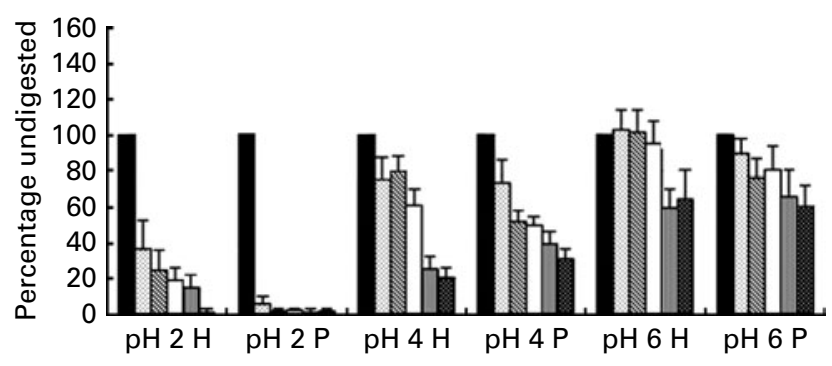

Fig. 4. Degradation profiles of lactoferrin after digestion of caprine whey protein concentrate (WPCG) with either human $(H)$ or porcine $(P)$ enzymes. Samples were extracted after simulated gastric digestion for 10,20 and $30 \mathrm{~min}$ at $\mathrm{pH} 2$, 4 or 6 followed by simulated duodenal digestion for 15 and $30 \mathrm{~min}$. (ם), $0 \mathrm{~min}$;

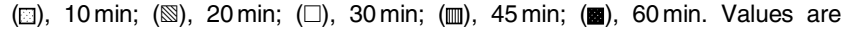
means, with standard deviations represented by vertical bars. Significant differences $(P<0.0001)$ were obtained only at $\mathrm{pH} 2$ for WPCG digested with human $(\mathrm{pH} 2 \mathrm{H})$ compared with porcine enzymes ( $\mathrm{pH} 2 \mathrm{P})$. markedly delayed degradation, and the digestion was overall very low at gastric $\mathrm{pH}$ 6. The difference in the amount of LF remaining after duodenal digestion with either porcine or human enzymes was not significant $(P>0.05)$.

\section{Peptides identified after in vitro gastroduodenal digestion}

Nano-LC MS/MS was used to identify the peptides produced by in vitro digestion after separating out peptides in the range of 100-7000 Da using gel filtration. Peptides from all the major proteins in the caprine whey including fragments of $\beta$-casein and $\kappa$-casein glycomacropeptide were identified (data not shown). Fig. 5 highlights the origin of peptides within the $\beta$-LG primary sequence when caprine whey was digested with human or porcine gastrointestinal enzymes using a gastric $\mathrm{pH}$ of 2 . Two replicates were run and the peptides identified in both replicates were included in the tabulation. An overview of the $\beta$-LG peptides identified after digestion of caprine whey using human and porcine enzymes (gastric $\mathrm{pH} \mathrm{2,4}$ and 6) are given in Supplemental Appendix $1 \mathrm{~A}$ and $\mathrm{B}$, respectively. Bovine $\beta-\mathrm{LG}$ was digested at gastric $\mathrm{pH} 2$ as a comparison with the digested $\beta-\mathrm{LG}$ in the caprine whey, and the peptides produced were identified. The sequence coverage was above $70 \%$ and almost identical areas in the $\beta$-LG primary sequence were covered irrespective of the enzyme source as seen in Fig. 6. More peptides were found when pure bovine $\beta-\mathrm{LG}$ was digested compared with the $\beta-L G$ in the digested caprine whey (Supplemental Appendix 1C).

\section{Discussion}

There are many reports in the literature on the physiological function of bioactive peptides produced by in vitro digestion 
$\begin{array}{lllllllllllllllllllllllllllllllllll}\text { Enzyme } & 1 & 2 & 3 & 4 & 5 & 6 & 7 & 8 & 9 & 10 & 11 & 12 & 13 & 14 & 15 & 16 & 17 & 18 & 19 & 20 & 21 & 22 & 23 & 24 & 25 & 26 & 27 & 28 & 29 & 30 & 31 & 32 & 33\end{array}$

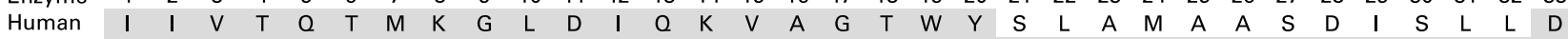

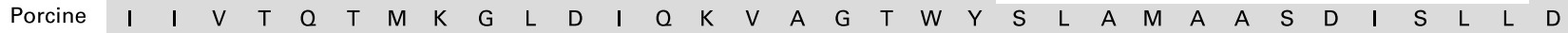

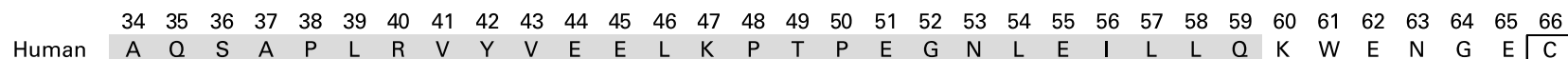
Porcine $A$ A

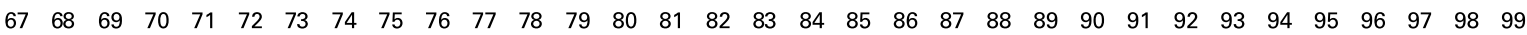

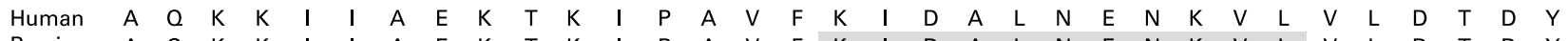

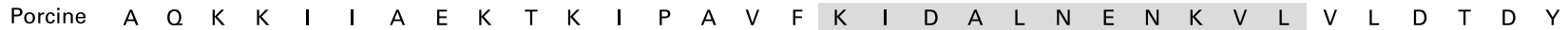

100101102103104105106107108109110111112113114115116117118119120121122123124125126127128129130131132

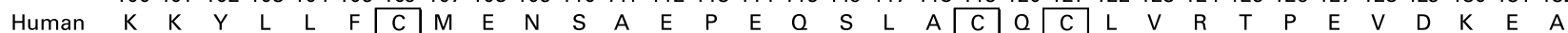

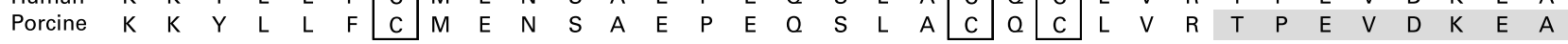

133134135136137138139140141142143144145146147148149150151152153154155156157158159160161162

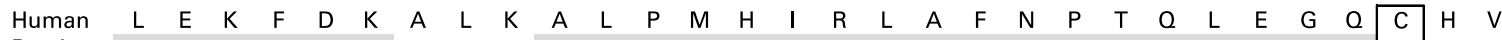

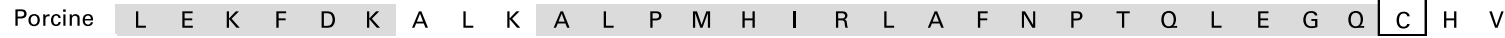

Fig. 5. Primary structure of caprine $\beta$-lactoglobulin. Grey sections denote the location of peptides identified by MS/MS after a two-step in vitro digestion assay. Step 1: gastric digestion at $\mathrm{pH}$ 2. Step 2: duodenal digestion at $\mathrm{pH} 8$. Disulfide bridges are located between Cys66 and Cys 160 and between Cys106 and Cys119/121.

of whey proteins using commercial enzymes from animal sources. There are, however, relatively few comparable data on digestion using human gastrointestinal enzymes. Since gastric $\mathrm{pH}$ seems to vary considerably in humans according to age, diet, health condition, etc, three different $\mathrm{pH}$ values, 2,4 and 6 , representing common variations in gastric $\mathrm{pH}$ were included in the present study.

As a general trend, the presented results showed that commercial porcine enzymes digested the caprine whey proteins more rapidly than the human digestive juices used at similar enzymic activities. Especially during the gastric digestion all the whey proteins seemed to be more rapidly degraded by the porcine pepsin than by human gastric juice irrespective of gastric $\mathrm{pH}$. Human gastric juice contains a combination of different pepsin isoforms. Pepsin A (3a, b, c and 1) constitutes about $90 \%$, whereas $10 \%$ of the proteases in non-stimulated human gastric juice is found to be pepsin C (gastricsin) ${ }^{(36)}$. The additional pepsin isoforms present in the human gastric juice may be less efficient at degrading the caprine whey proteins than porcine pepsin A alone or their activities may have different $\mathrm{pH}$-optima.

Furthermore, Tang et al. ${ }^{(37)}$ demonstrated how the proteolytic rate of gastricsin and pepsin depends on the substrate used. To determine the enzymic activity of the human gastric juices and porcine pepsin $\mathrm{A}$, the substrate employed was $\mathrm{Hb}$. When using a complex substrate such as whey the various pepsin isoforms may have different affinities for whey proteins as compared with their affinity for $\mathrm{Hb}$.

In general, we observed that the lower the $\mathrm{pH}$ during the gastric digestion, the more degraded were the proteins in both steps. At gastric $\mathrm{pH} 2$ all the proteins were significantly more degraded with porcine pepsin compared with human gastric juices $(P<0.05)$ especially for the minor whey proteins. Further degradation with porcine pancreatic enzymes or human duodenal juices showed only minor difference in the amount of intact protein remaining. Gastric digestion at $\mathrm{pH} 4$ resulted in a significantly lower degradation compared with $\mathrm{pH} 2$ for LF, SA and the immunoglobulins $(P<0.05)$. At pH 6 most of the proteins resisted the gastric digestion and the duodenal digestion was even more delayed.

The most resistant protein seemed to be $\beta$-LG and $\alpha$-LA which were hardly degraded during gastric digestion irrespective of $\mathrm{pH}$. This is in agreement with Chatterton et al. ${ }^{(38)}$, who showed that $\alpha$-LA and $\beta$-LG in bovine milk digested with human neonatal gastric juice were more resistant to

\begin{tabular}{|c|c|c|c|c|c|c|c|c|c|c|c|c|c|c|c|c|c|c|c|c|c|c|c|c|c|c|c|c|c|c|c|c|c|}
\hline \multirow{4}{*}{$\begin{array}{l}\text { Enzyme } \\
\text { Human } \\
\text { Porcine }\end{array}$} & 1 & 2 & 3 & 4 & 5 & 6 & 7 & 8 & 9 & 10 & 11 & 12 & 13 & 14 & 15 & 16 & 17 & 18 & 19 & 20 & 21 & 22 & 23 & 24 & 25 & 26 & 27 & 28 & 29 & 30 & 31 & 32 & 33 \\
\hline & $\mathrm{L}$ & 1 & V & $\mathrm{T}$ & 0 & $\mathrm{~T}$ & $M$ & $\mathrm{~K}$ & $\mathrm{G}$ & $\mathrm{L}$ & D & 1 & $\mathrm{Q}$ & $\mathrm{K}$ & V & $A$ & G & $\mathrm{T}$ & W & $Y$ & $S$ & $\mathrm{~L}$ & $A$ & $M$ & A & $A$ & $\mathrm{~S}$ & D & 1 & $S$ & $\mathrm{~L}$ & L & D \\
\hline & L & 1 & V & $\mathrm{T}$ & 0 & $T$ & $M$ & $\mathrm{~K}$ & G & $\mathrm{L}$ & D & 1 & Q & K & V & A & G & $\mathrm{T}$ & W & $Y$ & $S$ & L & A & $M$ & A & A & $S$ & D & 1 & $S$ & L & L & D \\
\hline & 34 & 35 & 36 & 37 & 38 & 39 & 40 & 41 & 42 & 43 & 44 & 45 & 46 & 47 & 48 & 49 & 50 & 51 & 52 & 53 & 54 & 55 & 56 & 57 & 58 & 59 & 60 & 61 & 62 & 63 & 64 & 65 & 66 \\
\hline \multirow{3}{*}{$\begin{array}{l}\text { Human } \\
\text { Porcine }\end{array}$} & A & Q & $S$ & $A$ & $P$ & L & $R$ & V & $\mathrm{Y}$ & V & $E$ & $E$ & L & K & $P$ & $\mathrm{~T}$ & $P$ & $E$ & G & D & L & $E$ & I & L & $L$ & Q & K & W & $E$ & $\mathrm{~N}$ & $\mathrm{G}$ & E & C \\
\hline & A & 0 & $S$ & A & $P$ & L & $R$ & V & $Y$ & V & $E$ & $E$ & L & K & $P$ & $\mathrm{~T}$ & $P$ & $E$ & G & D & L & $E$ & I & L & 1 & Q & $\mathrm{K}$ & W & $E$ & $\mathrm{~N}$ & G & $E$ & C \\
\hline & 67 & 68 & 69 & 70 & 71 & 72 & 73 & 74 & 75 & 76 & 77 & 78 & 79 & 80 & 81 & 82 & 83 & 84 & 85 & 86 & 87 & 88 & 89 & 90 & 91 & 92 & 93 & 94 & 95 & 96 & 97 & 98 & 99 \\
\hline \multirow{2}{*}{$\begin{array}{l}\text { Human } \\
\text { Porcine }\end{array}$} & $A$ & 0 & K & $\mathrm{K}$ & 1 & 1 & A & $E$ & $K$ & $\mathrm{~T}$ & $\mathrm{~K}$ & 1 & $P$ & A & V & $F$ & K & I & D & A & L & $\mathrm{N}$ & $E$ & $\mathrm{~N}$ & K & V & $\mathrm{L}$ & V & L & D & $\mathrm{T}$ & D & $Y$ \\
\hline & 100 & 101 & 102 & 103 & 104 & 105 & 106 & 107 & 108 & 109 & 110 & 111 & 112 & 113 & 114 & 115 & 116 & 117 & 118 & 119 & 120 & 121 & 122 & 123 & 124 & 125 & 126 & 127 & 128 & 129 & 130 & 131 & 132 \\
\hline \multirow{2}{*}{$\begin{array}{l}\text { Human } \\
\text { Porcine }\end{array}$} & $\mathrm{K}$ & K & $Y$ & L & L & $F$ & C & $\mathrm{M}$ & $E$ & $\mathrm{~N}$ & $S$ & A & $E$ & $P$ & $E$ & Q & $S$ & L & V & $\mathrm{C}$ & 0 & C & L & V & $R$ & $\mathrm{~T}$ & $P$ & $E$ & V & D & D & $E$ & A \\
\hline & $\mathrm{K}$ & K & $Y$ & L & $\mathrm{L}$ & $\mathrm{F}$ & C & $\mathrm{M}$ & $\mathrm{E}$ & $\mathrm{N}$ & S & $A$ & E & $P$ & $\mathrm{E}$ & 0 & $S$ & $\mathrm{~L}$ & V & C & $\mathrm{Q}$ & C & $\mathrm{L}$ & V & $R$ & $\mathrm{~T}$ & $P$ & E & V & D & D & $\mathrm{E}$ & A \\
\hline
\end{tabular}

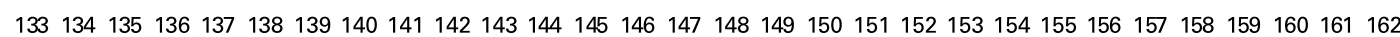

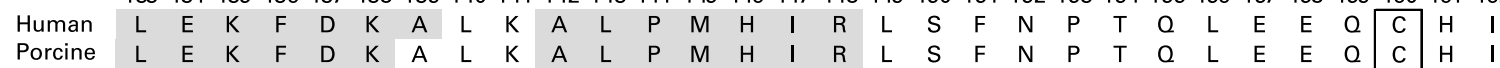

Fig. 6. Primary structure of bovine $\beta$-lactoglobulin. Grey sections denote the location of peptides identified by MS/MS after a two-step in vitro digestion assay. Step 1: gastric digestion at $\mathrm{pH}$ 2. Step 2: duodenal digestion at $\mathrm{pH} 8$. Disulfide bridges are located between Cys66 and Cys160 and between Cys106 and Cys119/121. 
degradation at $\mathrm{pH}$ above 4 compared with $\mathrm{pH} 2$. Schmidt et al. ${ }^{(39)}$ also showed a marked decrease in peptic degradation of $\alpha$-LA at $\mathrm{pH} 4$ compared with $\mathrm{pH} 2$ and 3, whereas $\beta-\mathrm{LG}$ was hardly degraded with pepsin at all $\mathrm{pH}$ values. However, as the whey proteins are digested, the high-molecular-weight proteins such as LF and SA may be cleaved to peptide fragments that may add to the bands of the smaller proteins when running SDS-PAGE. This could make the quantification of the degradation of the low-molecular-weight proteins ( $\beta$-LG and $\alpha$-LA) somewhat inaccurate, and is probably the reason why values above $100 \%$ were recorded for these proteins during digestion (Table 1).

When studying the digestion of proteins, individual variations in gastric $\mathrm{pH}$ may be taken into consideration ${ }^{(1)}$. When food is ingested, the $\mathrm{pH}$ in the stomach tends to rise depending on the composition and quantity of the meal, but decreases gradually as $\mathrm{HCl}$ is secreted and the stomach empties ${ }^{(1,17,38)}$. Individuals treated for gastrointestinal reflux disease with proton pump inhibitors (PPI) have a dramatically reduced secretion of $\mathrm{HCl}$, and as a result the gastric $\mathrm{pH}$ is kept well above $4^{(16,40)}$. At this elevated $\mathrm{pH}$, degradation of normal food proteins may be significantly impaired compared with the digestion observed at low gastric $\mathrm{pH}$. This $\mathrm{pH}$-related resistance to hydrolysis can affect the allergenicity of food proteins as epitopes can either remain stable or be degraded $^{(41)}$. Increased gastric $\mathrm{pH}$ could also possibly result in the production of bioactive peptides further down the gastrointestinal tract due to delayed digestion in addition to delayed release of amino acids.

The reduced gastric digestion by human gastric juices compared with porcine pepsin was to some extent compensated for by the activity of human duodenal juices (Table 1). The presence of bile salts in the duodenal juice used may also affect the proteolytic activity. Gass et $a .^{(42)}$ demonstrated that the addition of a $10 \mathrm{mmol} / \mathrm{l}$ physiological bile acid mixture significantly enhanced the digestion of $\beta-\mathrm{LG}$ and BSA by trypsin and chymotrypsin. The concentration of bile salts in the fasting state varies widely among individuals, but is usually within the range of $2 \cdot 6-6 \cdot 4 \mathrm{~mm}^{(1,17)}$. Postprandial duodenal bile salt concentration has been shown to peak 30 min after ingestion of a test meal ${ }^{(1,43)}$, reaching a mean of $14.5 \mathrm{mmol} / \mathrm{l}$. The human duodenal juice used in the present study was collected in a semi-fasting state (secretion stimulated by amino acids and sucrose) and therefore probably much less bile salts are present compared with duodenal juice collected after administration of a meal. However, the yellow colour of the human duodenal juices (bilirubin) indicated the presence of bile salts that in increased amounts may enhance the proteolysis compared with the porcine pancreatic enzyme mixture (Corolase PP), which, according to the manufacturer, contains only traces of bile salts.

The peptide profile of $\beta-\mathrm{LG}$ was studied in more detail since this protein is known to be rather resistant to degradation by $\operatorname{pepsin}^{(44,45)}$. The $\beta$-LG peptide profiles of the digested WPCG confirmed a more extensive degradation by porcine enzymes with a higher amount of peptides detected compared with the digestion with human enzymes.

The identified peptides released after digestion with human enzymes compared with the porcine enzymes differed to some extent. No peptides containing any of the cysteine groups after digestion of bovine $\beta-\mathrm{LG}$ was detected. Shorter peptides covering $\beta$-LG Cys160 were, on the other hand, identified in one of the replicates of the digested WPCG. Pecquet et al. ${ }^{(46)}$ identified a peptide consisting of fragment 61-69 linked to fragment 149-162 via the disulfide bond Cys66-Cys160. The digested $\beta$-LG may contain intact cyclic peptides of various lengths linked through Cys106-Cys119/121 and/or Cys66-Cys160. These peptides were, however, not identified, indicating that either larger intact cyclic peptides or fragments too small to be detected by our method were produced.

To conclude, the present study compared the in vitro gastrointestinal digestion of caprine whey proteins by using either human or porcine enzymes at different gastric $\mathrm{pH}$ values. Differences in the degradation profiles of the individual proteins indicated that perhaps human digestive enzymes should be preferred over pure commercial enzymes from other species when mimicking human digestion. Elevated gastric $\mathrm{pH}$ resulted in delayed protein digestion irrespective of the enzyme source. However, further studies are needed to establish if there is a clinical significance for this finding.

\section{Acknowledgements}

The present study was supported by the Norwegian University of Life Sciences.

We also greatly appreciated the excellent technical assistance offered by Toril Anne Grønset and Jack-Ansgar Bruun at The Troms $\varnothing$ University Proteomic Platform (TUPP) where all mass spectrometrical analyses were performed.

We wish to acknowledge Irene Comi for her helpful advice and laboratory assistance during HPLC work. The statistical expertise of Thomas Ulleberg was also greatly appreciated.

E. K. E. performed most of the experiments as well as writing the manuscript. H. H. donated his gastric and duodenal juices and assisted when performing the enzymic analyses. E. J. suggested the MS techniques to be used and helped with the interpretation of the acquired Mascot peptide files. R. A. performed the digestion of bovine $\beta-L G$, prefractionation and preparation for gel filtration. T. G. D. and M. J. participated in the research planning and interpretation of data. G. V. coordinated the research and designed the experiments. All authors contributed during the research planning, discussion of the results as well as during the revision of the manuscript and have approved the final version.

The authors report no conflict of interest.

Supplemental Appendix 1 is available online only at http:// journals.cambridge.org/action/displayJournal?jid = bjn

\section{References}

1. Dressman JB, Amidon GL, Reppas C, et al. (1998) Dissolution testing as a prognostic tool for oral drug absorption: immediate release dosage forms. Pharm Res 15, 11-22.

2. Moreno FJ (2007) Gastrointestinal digestion of food allergens: effect on their allergenicity. Biomed Pharmacother 61, 50-60.

3. Ekmekcioglu C (2002) A physiological approach for preparing and conducting intestinal bioavailability studies using experimental systems. Food Chem 76, 225-230.

4. Gardner ML (1988) Gastrointestinal absorption of intact proteins. Annu Rev Nutr 8, 329-350.

5. Bernasconi E, Fritsche R \& Corthesy B (2006) Specific effects of denaturation, hydrolysis and exposure to Lactococcus lactis 
on bovine $\beta$-lactoglobulin transepithelial transport, antigenicity and allergenicity. Clin Exp Allergy 36, 803-814.

6. Hernández-Ledesma B, Quirós A, Amigo L, et al. (2007) Identification of bioactive peptides after digestion of human milk and infant formula with pepsin and pancreatin. Int Dairy J 17, 42-49.

7. Bordenave S, Sannier F, Ricart G, et al. (2000) Characterization of a goat whey peptic hydrolysate produced by an ultrafiltration membrane enzymic reactor. J Dairy Res 67, 551-559.

8. Schmelzer CE, Schops R, Reynell L, et al. (2007) Peptic digestion of $\beta$-casein. Time course and fate of possible bioactive peptides. J Chromatogr A 1166, 108-115.

9. Amiot J, Germain L, Turgeon S, et al. (2004) Peptides from milk protein hydrolysates to improve the growth of human keratinocytes in culture. Int Dairy $J$ 14, 619-626.

10. Kim SB, Ki KS, Khan MA, et al. (2007) Peptic and tryptic hydrolysis of native and heated whey protein to reduce its antigenicity. J Dairy Sci 90, 4043-4050.

11. Whitcomb DC \& Lowe ME (2007) Human pancreatic digestive enzymes. Dig Dis Sci 52, 1-17.

12. Roberts NB (2006) Review Article: human pepsins - their multiplicity, function and role in reflux disease. Aliment Pharmacol Ther 24, Suppl. 2, 2-9.

13. Thomas K, Aalbers M, Bannon GA, et al. (2004) A multilaboratory evaluation of a common in vitro pepsin digestion assay protocol used in assessing the safety of novel proteins. Regul Toxicol Pharmacol 39, 87-98.

14. Fallingborg J (1999) Intraluminal pH of the human gastrointestinal tract. Dan Med Bull 46, 183-196.

15. Dressman JB, Berardi RR, Dermentzoglou LC, et al. (1990) Upper gastrointestinal (GI) $\mathrm{pH}$ in young, healthy men and women. Pharm Res 7, 756-761.

16. Hunt RH, Armstrong D, James C, et al. (2005) Effect on intragastric $\mathrm{pH}$ of a PPI with a prolonged plasma half-life: comparison between tenatoprazole and esomeprazole on the duration of acid suppression in healthy male volunteers. Am J Gastroenterol 100, 1949-1956.

17. Kalantzi L, Goumas K, Kalioras V, et al. (2006) Characterization of the human upper gastrointestinal contents under conditions simulating bioavailability/bioequivalence studies. Pharm Res 23, 165-176.

18. Russell TL, Berardi RR, Barnett JL, et al. (1993) Upper gastrointestinal $\mathrm{pH}$ in seventy-nine healthy, elderly, North American men and women. Pharm Res 10, 187-196.

19. McCloy RF, Greenberg GR \& Baron JH (1984) Duodenal pH in health and duodenal ulcer disease: effect of a meal. Coca-Cola, smoking, and cimetidine. Gut 25, 386-392.

20. Miranda G, Mahe MF, Leroux C, et al. (2004) Proteomic tools to characterize the protein fraction of Equidae milk. Proteomics 4, 2496-2509.

21. Park YW (2006) Goat milk - chemistry and nutrition. In Handbook of Milk of Non-Bovine Mammals, 1st ed., pp. 34-58 [YW Park and GFW Haenlein, editors]. Oxford: Blackwell Publishing.

22. Ha E \& Zemel MB (2003) Functional properties of whey, whey components, and essential amino acids: mechanisms underlying health benefits for active people (review). J Nutr Biochem 14, 251-258.

23. Katsanos CS, Chinkes DL, Paddon-Jones D, et al. (2008) Whey protein ingestion in elderly persons results in greater muscle protein accrual than ingestion of its constituent essential amino acid content. Nutr Res 28, 651-658.

24. Pihlanto-Leppala A (2000) Bioactive peptides derived from bovine whey proteins: opioid and ACE-inhibitory peptides. Trends Food Sci Technol 11, 347-356.

25. FitzGerald RJ \& Meisel H (1999) Lactokinins: whey proteinderived ACE inhibitory peptides. Nahrung 43, 165-167.

26. Moller NP, Scholz-Ahrens KE, Roos N, et al. (2008) Bioactive peptides and proteins from foods: indication for health effects. Eur J Nutr 47, 171-182.
27. Hernández-Ledesma B, Recio I \& Amigo L (2008) $\beta$-Lactoglobulin as source of bioactive peptides. Amino Acids 35, 257-265.

28. Almaas H, Holm H, Langsrud T, et al. (2006) In vitro studies of the digestion of caprine whey proteins by human gastric and duodenal juice and the effects on selected microorganisms. Br J Nutr 96, 562-569.

29. Almaas H, Cases A-L, Devold TG, et al. (2006) In vitro digestion of bovine and caprine milk by human gastric and duodenal enzymes. Int Dairy J 16, 961-968.

30. Eriksen EK, Vegarud GE, Langsrud T, et al. (2008) Effect of milk proteins and their hydrolysates on in vitro immune responses. Small Rumin Res 79, 29-37.

31. Holm H, Krogdahl A \& Hanssen LE (1988) High and low inhibitor soybean meals affect human duodenal proteinase activity differently: in vitro comparison of proteinase inhibition. J Nutr 118, 521-525.

32. Sánchez-Chiang L, Cisternas E \& Ponce O (1987) Partial purification of pepsins from adult and juvenile salmon fish Oncorhynchus keta. Effect of $\mathrm{NaCl}$ on proteolytic activities. Comp Biochem Physiol B 87, 793-797.

33. Krogdahl A \& Holm H (1979) Inhibition of human and rat pancreatic proteinases by crude and purified soybean proteinase inhibitors. J Nutr 109, 551-558.

34. Laemmli UK (1970) Cleavage of structural proteins during the assembly of the head of bacteriophage T4. Nature 227, 680-685.

35. Shevchenko A, Wilm M, Vorm O, et al. (1996) A strategy for identifying gel-separated proteins in sequence databases by MS alone. Biochem Soc Trans 24, 893-896.

36. Jones AT, Balan KK, Jenkins SA, et al. (1993) Assay of gastricsin and individual pepsins in human gastric juice. J Clin Pathol 46, 254-258.

37. Tang J, Mills J, Chiang L, et al. (1967) Gastric pepsin, mucus and clinical secretory studies. I. Gastric pepsin and pepsin inhibitors. Comparative studies on the structure and specificity of human gastricsin, pepsin and zymogen. Ann N Y Acad Sci 140, 688-696.

38. Chatterton DEW, Rasmussen JT, Heegaard CW, et al. (2004) In vitro digestion of novel milk protein ingredients for use in infant formulas: research on biological functions. Trends Food Sci Technol 15, 373-383.

39. Schmidt DG, Meijer RJ, Slangen CJ, et al. (1995) Raising the $\mathrm{pH}$ of the pepsin-catalysed hydrolysis of bovine whey proteins increases the antigenicity of the hydrolysates. Clin Exp Allergy 25, 1007-1017.

40. Armstrong D (2004) Review article: gastric pH - the most relevant predictor of benefit in reflux disease? Aliment Pharmacol Ther 20, Suppl. 5, 19-26, 38-39.

41. Monaci L, Tregoat V, van Hengel A, et al. (2006) Milk allergens, their characteristics and their detection in food: a review. Eur Food Res Technol 223, 149-179.

42. Gass J, Vora H, Hofmann AF, et al. (2007) Enhancement of dietary protein digestion by conjugated bile acids. Gastroenterology 133, 16-23.

43. Fausa O (1974) Duodenal bile acids after a test meal. Scand $J$ Gastroenterol 9, 567-570.

44. Mota MVT, Ferreira IMPLVO, Oliveira MBP, et al. (2006) Trypsin hydrolysis of whey protein concentrates: characterization using multivariate data analysis. Food Chem 94, 278-286.

45. Pintado ME \& Malcata FX (2000) Hydrolysis of ovine, caprine and bovine whey proteins by trypsin and pepsin. Bioprocess Eng 23, 275-282.

46. Pecquet S, Bovetto L, Maynard F, et al. (2000) Peptides obtained by tryptic hydrolysis of bovine $\beta$-lactoglobulin induce specific oral tolerance in mice. J Allergy Clin Immunol 105, 514-521. 